\title{
Kształtowanie przestrzeni - sprawny system Czy chaos? Miejscowy plan zagospodarowania przestrzennego - parametry zabudowy
}

\author{
Anna Wieczorek
}

\section{STRESZCZENIE}

Artykuł jest kolejnym z serii artykułów o systemie kształtowania przestrzeni w Polsce i ostatnim z trzech dotyczacych zakresu stanowienia miejscowego planu zagospodarowania przestrzennego. Jest uzupełnieniem i rozszerzeniem artykułu pt. Ksztattowanie przestrzeni - sprawny system czy chaos? Miejscowy plan zagospodarowania przestrzennego - zakres stanowienia.

W artykule odniesiono się do wybranych parametrów zabudowy, o których mowa w przepisie art. 15 ust. 2 pkt 6 ustawa o planowaniu i zagospodarowaniu przestrzennym. Wskazano na wieloznaczność użytych w tym przepisie pojęć oraz samego pojęcia zabudowa, co utrudnia sporządzanie miejscowych planów zagospodarowania przestrzennego.

Świadomie powtórzono niektóre fragmenty artykułu pt. Kształtowanie przestrzeni - sprawny system czy chaos? Miejscowy plan zagospodarowania przestrzennego - zakres stanowienia.

Osobom, które go nie czytały, ułatwi to zrozumienie zagadnień omawianych w niniejszym artykule.

Dla zachowania precyzji wypowiedzi posłużono się szeregiem cytatów. Artykuł oparto na przepisach prawa obowiązujących na koniec października $2021 \mathrm{r}$.

Słowa kluczowe: miejscowy plan zagospodarowana przestrzennego, powierzchnia zabudowy, intensywność zabudowy, wysokość zabudowy, powierzchnia biologicznie czynna

\section{Wprowadzenie}

Podstawa kształtowania przestrzeni w gminach są miejscowe plany zagospodarowania przestrzennego, w skrócie plany miejscowe, będące aktami prawa miejscowego. Ich zakres stanowienia określa ustawa o planowaniu i zagospodarowaniu przestrzennym (upzp).

Artykuł jest kolejnym z serii artykułów o systemie kształtowania przestrzeni w Polsce i ostatnim z trzech dotyczących zakresu stanowienia miejscowego planu zagospodarowania przestrzennego. Jest uzupełnieniem i rozszerzeniem artykułu pt. Kształtowanie przestrzeni sprawny system czy chaos? Miejscowy plan zagospodarowania przestrzennego - zakres stanowienia. Odnosi się do wybranych parametrów zabudowy, o których mowa w art. 15 ust. 2 pkt 6 ustawy o planowaniu i zagospodarowaniu przestrzennym (cytat powyższego przepisu poniżej). Wskazuje na wieloznaczność użytych w tym przepisie pojęć i potwierdza tezę o braku precyzji zakresu stanowienia planów miejscowych. 
W planie miejscowym określa się obowiązkowo:

„zasady kształtowania zabudowy oraz wskaźniki zagospodarowania terenu, maksymalną i minimalną intensywność zabudowy jako wskaźnik powierzchni całkowitej zabudowy w odniesieniu do powierzchni działki budowlanej, minimalny udział procentowy powierzchni biologicznie czynnej w odniesieniu do powierzchni działki budowlanej, maksymalną wysokość zabudowy, minimalną liczbę miejsc do parkowania w tym miejsca przeznaczone na parkowanie pojazdów zaopatrzonych w kartę parkingową i sposób ich realizacji oraz linie zabudowy i gabaryty obiektów" [art. 15 ust. 2 pkt 6 upzp].

Rozporządzenie w sprawie wymaganego zakresu projektu miejscowego planu zagospodarowania przestrzennego (rozp. mpzp) stanowi, że ustalenia dotyczące "parametrów i wskaźników kształtowania zabudowy oraz zagospodarowania terenu powinny zawierać w szczególności określenie linii zabudowy, wielkości powierzchni zabudowy w stosunku do powierzchni działki lub terenu, w tym udziału powierzchni biologicznie czynnej, a także gabarytów i wysokości projektowanej zabudowy oraz geometrii dachu" [§ 4 pkt 6 rozp. mpzp].

Lista parametrów i wskaźników kształtowania zabudowy jest obszerna. W artykule odniesiono się do tych, które budzą najwięcej kontrowersji. Z doświadczeń autora wynika, że sa to powierzchnia zabudowy, intensywność zabudowy i wysokość zabudowy oraz powierzchnia biologicznie czynna.

Ustawa o planowaniu i zagospodarowaniu przestrzennym i wydane na jej podstawie powyższe rozporządzenie nie definiuja pojęć powierzchnia zabudowy, powierzchnia biologicznie czynna i wysokość zabudowy, a ustawowa definicja intensywności zabudowy jest wieloznaczna.

W takiej sytuacji sporządzający plan miejscowy ma prawo i obowiązek zdefiniowania brakujących i niejednoznacznych określeń. Stanowi o tym rozporządzenie w sprawie „Zasad techniki prawodawczej" (rozp. ztp). Należy zastosować odesłanie do definicji zawartych w przepisach odrębnych [§ 156 Załącznika do rozp. ztp]. Prawo nie przesądza, do którego przepisu stosować odesłanie, kiedy dwa przepisy odrębne definiują różnie to samo pojęcie. Zabronione jest jedynie odesłanie do określenia bliskoznacznego. „Do oznaczenia jednakowych pojęć używa się jednakowych określeń, a różnych pojęć nie oznacza się tymi samymi określeniami." [§ 10 Załącznika do rozp. ztp].

Jeżeli w przepisach odrębnych nie ma potrzebnej definicji, to można powołać normę, albo opracować „własną" definicję, opierając się np. na słownikach.

W artykule poddano analizie wybrane przepisy odrębne, dotyczace omawianych parametrów zabudowy. Warto przypomnieć, o czym była już mowa w poprzednich artykułach dotyczących zakresu stanowienia planów miejscowych, że pojęcie zabudowa nie ma definicji w polskim systemie prawnym. W rozporządzeniu w sprawie warunków technicznych jakim powinny odpowiadać budynki i ich usytuowanie (rozp.w.t.) występuje w zestawieniu z innymi określeniami: zabudowa śródmiejska, zabudowa jednorodzinna i zabudowa zagrodowa. Z analizy powyższych definicji można wnioskować, że zabudowa to: zespoły budynków albo zespoły obiektów budowlanych (budynków, budowli i obiektów małej architektury) oraz urządzeń budowlanych, o których mowa np. w ustawie Prawo budowlane. 
Brak jednoznacznego określenia, czym jest zabudowa rzutuje na całość zakresu stanowienia planu miejscowego, prowadząc do jego wieloznaczności i braku precyzji.

Nie jest przedmiotem artykułu szczegółowa analiza, jak rozumiane są pojęcia powierzchnia zabudowy, intensywność zabudowy i wysokość zabudowy oraz powierzchnia biologicznie czynna w obowiązujących planach miejscowych, orzecznictwie i rozstrzygnięciach nadzorczych wojewodów, literaturze dotyczącej zakresu stanowienia planu miejscowego oraz w dokumentach rządowych i sejmowych.

Do powyższych zagadnień odniesiono się w sposób bardzo ogólny, bez powoływania się na konkretne plany miejscowe czy rozstrzygnięcia nadzorcze wojewodów.

Dla zachowania precyzji wypowiedzi posłużono się szeregiem cytatów z wybranych aktów prawa.

\section{Powierzchnia zabudowy}

O powierzchni zabudowy jest mowa w kilku aktach prawa, będących przepisami odrębnymi w rozumieniu ustawy o planowaniu i zagospodarowaniu przestrzennym oraz w normach.

Rozporządzenie w sprawie ewidencji gruntów i budynków (rozp. eg) określa jak oblicza się pole powierzchni zabudowy oraz zawiera wykaz elementów budynku, które nie wchodzą w skład powierzchni zabudowy.

„Pole powierzchni zabudowy oblicza się na podstawie prostokatnego rzutu na płaszczyznę poziomą zewnętrznych płaszczyzn ścian zewnętrznych kondygnacji przyziemnej budynku, a w budynkach posadowionych na filarach na podstawie rzutu zewnętrznych płaszczyzn ścian zewnętrznych kondygnacji opartej na tych filarach." [§ 18 ust 2 rozp. eg].

„W przypadku budynków posiadających tylko kondygnacje podziemne pole powierzchni zabudowy oblicza się na podstawie prostokątnego rzutu na płaszczyznę poziomą zewnętrznych krawędzi tego budynku." [§ 18 ust 3 rozp. eg].

„W bazie danych ewidencyjnych oprócz konturu budynku ujawnia się bloki budynków oraz obiekty budowlane trwale związane z budynkiem, takie jak: taras, weranda, wiatrołap, schody, podpora, rampa, wjazd do podziemia, podjazd dla osób niepełnosprawnych." [§ 19 rozp. eg].

Rozporządzenie w sprawie szczegółowego zakresu i formy projektu budowlanego (rozp. fpb) stanowi, że projekt budowlany zawiera zestawienie szeregu powierzchni, w tym „powierzchni zabudowy projektowanych i istniejących obiektów budowlanych, przy czym powierzchnię zabudowy budynku pomniejsza się o powierzchnię części zewnętrznych budynku, takich jak: tarasy naziemne i podparte słupami, gzymsy oraz balkony" [§ 14 pkt 4 ppkt a rozp. fpb].

Powierzchnie budynków określa się zgodnie z Polskimi Normami wymienionymi w załączniku do tego rozporządzenia [§ 12 rozp. fpb]. W załączniku powołano normę PN-ISO 9836, bez sprecyzowania, czy chodzi o normę PN-ISO 9836:1997 (norma wycofana 
w rozumieniu Polskiego Komitetu Normalizacji), czy normę PN-ISO 9836:2015-12 (norma aktualna w rozumieniu Polskiego Komitetu Normalizacji).

Według normy PN-ISO 9836:1997:

„Przez powierzchnię zabudowy rozumie się powierzchnię terenu zajętą przez budynek w stanie wykończonym." [punkt 5.1.2.1]

„Powierzchnia zabudowy jest wyznaczana przez rzut pionowy zewnętrznych krawędzi budynku na powierzchnię terenu.

Do powierzchni zabudowy nie wlicza się:

- powierzchni obiektów budowlanych ani ich części nie wystających ponad powierzchnię terenu;

- powierzchni elementów drugorzędnych, np. schodów zewnętrznych, ramp zewnętrznych, daszków, markiz, występów dachowych, oświetlenia zewnętrznego;

- powierzchni zajmowanej przez wydzielone obiekty pomocnicze (np. szklarnie, altany, szopy)" [punkt 5.1.2.2].

Według normy PN-ISO 9836:2015-12:

„Przez powierzchnię zabudowy rozumie się powierzchnię terenu zajętą przez budynek w stanie wykończonym." [punkt 5.1.2.1]

„Powierzchnia zabudowy jest wyznaczona przez rzut wymiarów zewnętrznych budynku na powierzchnię terenu.

Do powierzchni zabudowy nie wlicza się powierzchni:

- elementów budynku ani ich części nie wystających ponad powierzchnię terenu;

- elementów drugorzędnych budynku, np. schodów zewnętrznych, ramp i pochylni zewnętrznych, daszków, markiz, okapów dachowych, oświetlenia zewnętrznego;

- zewnętrznych obiektów pomocniczych, np. szklarni i przybudówek" [punkt 5.1.2.2].

Obie normy są niejednoznaczne, ponieważ pod pojęciem powierzchnia zabudowy można rozumieć - powierzchnię terenu zajęta przez budynek, czyli rzut kondygnacji stykajacej się z terenem [punkt 5.1.2.1] albo - rzut pionowy zewnętrznych krawędzi budynku na powierzchnię terenu, czyli rzut kondygnacji o największych wymiarach [punkt 5.1.2.2].

Zawarte w rozporządzeniu w sprawie ewidencji gruntów i budynków oraz w normach definicje powierzchni zabudowy w wielu przypadkach oznaczają to samo. Najkrócej mówiąc, to rzut zewnętrznych ścian budynku na płaszczyznę poziomą terenu. Do powierzchni zabudowy nie wlicza się takich części budynku, jak: tarasy, werandy, wiatrołapy, schody, rampy. Podstawowa różnica polega na tym, że definicja z ewidencji gruntów i budynków jest bardziej precyzyjna. Określa np. jak wyznaczać powierzchnię zabudowy budynku, który ma inny rzut kondygnacji stykającej się z powierzchnią terenu niż rzuty innych kondygnacji, albo budynku posadowionego na filarach.

Zupełnie inaczej powierzchnię zabudowy definiuje rozporządzenie w sprawie przedsięwzięć mogących znacząco oddziaływać na środowisko (rpzoś). Pod pojęciem powierzchnia zabudowy należy rozumieć "powierzchnię terenu zajęta przez obiekty budowlane oraz pozostała powierzchnię przeznaczoną do przekształcenia, w tym tymczasowego, $\mathrm{w}$ celu realizacji przedsięwzięcia" [§ 1 ust. 2 pkt 2 rproś]. 
Wszystkie trze omawiane rozporządzenia sa przepisami odrębnymi w rozumieniu ustawy o planowaniu i zagospodarowaniu przestrzennym, a plan miejscowy sporządza się zgodnie z tymi przepisami [art. 15 ust. 1 upzp]. Zastosowanie odesłania do każdego z tych przepisów dopuszcza rozporządzenie w sprawie „Zasad techniki prawodawczej”. Autor artykułu zna jednak przypadek, kiedy odesłanie do rozporządzenia w sprawie ewidencji gruntów i budynków organ nadzoru uznał za istotne naruszenie prawa. Tymczasem za odesłaniem do tego rozporządzenia przemawia najwięcej. Ustawa Prawo geodezyjne i kartograficzne (ugk) stanowi, że podstawa planowania przestrzennego są dane zawarte w ewidencji gruntów i budynków [art. 21 ust. 1 ugk]. Plan miejscowy sporządza się w skali 1:1000, z wykorzystaniem urzędowych kopii map zasadniczych albo w przypadku ich braku map katastralnych, gromadzonych w państwowym zasobie geodezyjnym i kartograficznym." [art. 16 ust. 1 upzp]. Na kopi mapy zasadniczej wykonuje się również część projektu budowlanego - projekt zagospodarowania działki lub terenu. Mapa zasadnicza zawiera dane z ewidencji gruntów i budynków.

Przed wydaniem pozwolenia na budowę organ, który je wydaje, sprawdza zgodność projektu budowanego z ustaleniami planu miejscowego. Definicje użyte w normach, powołanych w rozporządzeniu w sprawie szczegółowego zakresu i formy projektu budowlanego w wielu przypadkach oznaczają to samo, co określenia użyte w ewidencji gruntów i budynków. Tam gdzie normy są niejednoznaczne, przy obliczaniu powierzchni zabudowy i tak trzeba się odnieść do definicji z ewidencji.

\section{Intensywność zabudowy}

Intensywność zabudowy definiuje art. 15 ust. 2 pkt 6 ustawy o planowaniu i zagospodarowaniu przestrzennym. To „wskaźnik powierzchni całkowitej zabudowy w odniesieniu do powierzchni działki budowlanej".

Pojęcie działka budowlana ma różniące się od siebie definicje: w ustawie o planowaniu i zagospodarowaniu przestrzennym, w ustawie o gospodarce nieruchomościami oraz w rozporządzeniu w sprawie warunków technicznych jakim powinny odpowiadać budynki i ich usytuowanie. Pozostaje bezspornym, że przy sporządzaniu planu miejscowego należy stosować definicję z ustawy o planowaniu i zagospodarowaniu przestrzennym.

Pojęcie powierzchnia całkowitej zabudowy nie ma definicji w żadnym z powszechnie obowiązujących aktów prawa, co oznacza, że sporządzający plan miejscowy ma prawo i obowiązek zdefiniowania tego określenia. Pojecie to jest bardzo różnie rozumiane przez sporządzających plany miejscowe, organy nadzoru i sądy.

Przykładowo, można spotkać określenia, że powierzchnia całkowitej zabudowy, to:

- suma powierzchni zabudowy,

albo

- $\quad$ suma powierzchni zabudowy, powierzchni części budynków, których nie wlicza się do powierzchni zabudowy oraz powierzchni budowli, obiektów małej architektury 
i urządzeń budowlanych, posadowionych w całości na terenie i ich części wystających nad powierzchnię terenu,

albo

- powierzchnia całkowita budynku, czyli suma powierzchni całkowitej wszystkich kondygnacji budynków w rozumieniu norm: PN-ISO 9836: 1997 i PN-ISO 9836:2015-12, albo

- $\quad$ suma powierzchni całkowitej wszystkich kondygnacji nadziemnych budynków.

Można się spotkać również z ustaleniem planu typu: intensywność zabudowy $=2$, co oznacza, że stosunek powierzchni całkowitej zabudowy do powierzchni działki budowlanej wynosi 2. Jeśli przykładowo powierzchnia działki budowlanej wynosi $1000 \mathrm{~m}^{2}$, to powierzchnia całkowitej zabudowy wynosi $2000 \mathrm{~m}^{2}$, tyle że nie wiadomo czym jest ta powierzchnia.

Za wyjatkowo kontrowersyjne można uznać utożsamianie powierzchni całkowitej zabudowy z powierzchnią całkowitą budynku. „Powierzchnie budynku określa się zgodnie z zasadami zawartymi w Polskiej Normie" [§ 12 rozp. fpb], a normy PN-ISO 9836 definiuja pojęcie powierzchnia całkowita budynku, jako sumę powierzchni całkowitej wszystkich jego kondygnacji. Skoro „różnych pojęć nie oznacza się tymi samymi określeniami” [§ 10 Załącznika do rozp. ztp], to takie postępowanie można uznać za naruszenie przepisów rozporządzenia w sprawie "Zasad techniki prawodawczej".

Tymczasem, doświadczenia autora artykułu wskazuja, że sporządzający plany miejscowe często uważaja, że powierzchnia całkowitej zabudowy to powierzchnia całkowita budynku, a organy nadzoru nie dostrzegają w tym naruszenia prawa. Można sądzić, że takie postępowanie wynika ze „swego rodzaju przyzwyczajenia”. Ustawa o planowaniu i zagospodarowaniu przestrzennym w brzmieniu pierwotnym z 2003 r. stanowiła, iż w planie miejscowym ustala się „parametry i wskaźniki kształtowania zabudowy oraz zagospodarowania terenu, w tym linie zabudowy, gabaryty obiektów i wskaźniki intensywności zabudowy" [art. 15 ust. 2 pkt 6 upzp w brzmieniu opublikowanym w Dz.U. z 2003 r. nr 80, poz. 717]. Ustawa nie definiowała wskaźników intensywności zabudowy, co pozwalało sporządzającym plany miejscowe na dużą dowolność w ich określaniu.

\section{Wysokość zabudowy}

Pojęcie wysokość zabudowy nie ma definicji w żadnym z powszechnie obowiązujących aktów prawa. Tym samym sporządzający plan miejscowy ma prawo i obowiązek zdefiniować to określenie.

Przyjmując, że zabudowa to zespoły budynków, można próbować stosować odesłanie do rozporządzenia w sprawie warunków technicznych, jakim powinny odpowiadać budynki i ich usytuowanie. „Wysokość budynku, służącą do przyporządkowania temu budynkowi odpowiednich wymagań rozporządzenia, mierzy się od poziomu terenu przy najniżej położonym wejściu do budynku lub jego części, znajdującym się na pierwszej kondygnacji nadziemnej budynku, do górnej powierzchni najwyżej położonego stropu, łącznie z grubością 
izolacji cieplnej i warstwy ją osłaniającej, bez uwzględniania wyniesionych ponad tę płaszczyznę maszynowni dźwigów i innych pomieszczeń technicznych, bądź do najwyżej położonego punktu stropodachu lub konstrukcji przekrycia budynku znajdującego się bezpośrednio nad pomieszczeniami przeznaczonymi na pobyt ludzi." [§ 6 rozp.w.t.].

Jeśli przyjąć, że zabudowa oznacza zespoły obiektów budowlanych i urządzeń budowlanych, to należy ustalić wysokość wszystkich tych obiektów, nie tylko budynków. Wymaga to opracowania stosownej definicji pojęcia wysokość zabudowy.

\section{Powierzchnia biologicznie czynna}

Pojęcie powierzchnia biologicznie czynna nie ma definicji w żadnym z powszechnie obowiązujących aktów prawa. Zdefiniowanie tego określenia należy do sporządzającego plan miejscowy.

W świetle przepisów rozporządzenia w sprawie "Zasad techniki prawodawczej", nie wolno mylić powierzchni biologicznie czynnej z określeniem bliskoznacznym - teren biologicznie czynny.

Teren biologicznie czynny, to „teren o nawierzchni urządzonej w sposób zapewniający naturalną wegetację roślin i retencję wód opadowych, a także $50 \%$ powierzchni tarasów i stropodachów z taką nawierzchnią oraz innych powierzchni zapewniających naturalna wegetację roślin, o powierzchni nie mniejszej niż $10 \mathrm{~m}^{2}$, oraz wodę powierzchniową na tym terenie" [§ 3 pkt 22 rozp.w.t.].

W planach miejscowych można spotkać odesłanie do powyższej definicji, jak i określenie, że powierzchnia biologicznie czynna, to:

- teren o nawierzchni urządzonej w sposób zapewniający naturalną wegetację roślin i retencję wód opadowych oraz wody powierzchniowe o dnie naturalnym, albo

- teren o nawierzchni urządzonej w sposób zapewniający naturalną wegetację roślin.

\section{Podsumowanie}

Analiza przepisów dotyczących parametrów kształtowania zabudowy potwierdza konkluzje zawarte w artykule pt. Kształtowanie przestrzeni - sprawny system czy chaos? Miejscowy plan zagospodarowania przestrzennego - zakres stanowienia.

Zakres stanowienia planów miejscowych jest mało precyzyjny, ponieważ w ustawie o planowaniu i zagospodarowaniu przestrzennym oraz w rozporządzeniu w sprawie wymaganego zakresu projektu miejscowego planu zagospodarowania brakuje definicji użytych w nim pojęć. Chaos pogłębiają określenia bliskoznaczne zawarte w przepisach odrębnych.

Porządkowanie prawa należy rozpoczać od zdefiniowania pojęcia zabudowa, a następnie na podstawie tej definicji sprecyzować czym jest powierzchnia zabudowy i wysokość 
zabudowy. Byłoby wskazane, żeby powyższe pojęcia miały te same definicje, jeśli są używane w różnych aktach prawa.

Zastanowienia wymaga, czy mając określona powierzchnię zabudowy, wysokość zabudowy i powierzchnię biologicznie czynną trzeba jeszcze określać intensywność zabudowy, która bez względu na sposób definiowania jest pochodną powyższych wskaźników.

\section{Materiały źródłowe}

Ustawy:

Ustawa z dnia 17 maja 1989 r. Prawo geodezyjne i kartograficzne (t.j. z dnia 1 października 2021 r. Dz.U. z 2021 r. poz. 1990 z późn. zm.), w skrócie ugk.

Ustawa z dnia 7 lipca 1994 r. Prawo budowlane (t.j. z dnia 7 lipca 2020 r. Dz.U. z 2020 r. poz. 1333 z późn. zm.).

Ustawa z dnia 21 sierpnia 1997 r. o gospodarce nieruchomościami (t.j. z dnia 17 września 2021 r. Dz.U. z 2021 r. poz. 1899).

Ustawa z dnia 27 marca 2003 r. o planowaniu i zagospodarowaniu przestrzennym (t.j. z dnia 31 marca 2021 r. Dz.U. z 2021 r. poz. 741 z późn. zm.), w skrócie upzp.

Rozporządzenia:

Rozporządzenie Ministra Infrastruktury z dnia 12 kwietnia 2002 r. w sprawie warunków technicznych jakim powinny odpowiadać budynki i ich usytuowanie (t.j. z 8 kwietnia 2019 r. Dz.U. z 2019 r. poz. 1065 z późn. zm.), w skrócie rozp.w.t.

Rozporządzenie Prezesa Rady Ministrów z dnia 20 czerwca 2002 r. w sprawie „Zasad techniki prawodawczej" (t.j. z dnia 29 lutego 2016 r. Dz.U. z 2016 r. poz. 283) w skrócie rozp. ztp.

Rozporządzenie Ministra Infrastruktury z dnia 26 sierpnia 2003 r. w sprawie wymaganego zakresu projektu miejscowego planu zagospodarowania przestrzennego (Dz.U. nr 164 z 2003 r. poz. 1587), w skrócie rozp. mpzp.

Rozporządzenie Rady Ministrów z dnia 10 września 2019 r. w sprawie przedsięwzięć mogących znacząco oddziaływać na środowisko (Dz.U. z 2019 r. poz. 1839), w skrócie rpzoś.

Rozporządzenie Ministra Rozwoju z dnia 11 września 2020 r. w sprawie szczegółowego zakresu i formy projektu budowlanego (Dz.U. z 2020 r. poz. 1609 z późn. zm.), w skrócie rozp. fpb. Rozporządzenie Ministra Rozwoju, Pracy i Technologii z dnia 27 lipca 2021 r. w sprawie ewidencji gruntów i budynków (Dz.U. z 2021 r. poz. 1390), w skrócie rozp. eg. 


\section{Imposing spatial order - an efficient system or chaos? Local spatial development plan - development parameters}

\section{ABSTRACT}

This paper is another in a series of articles on the spatial planning system in Poland and the last of three on the scope of constituting local spatial development plans. It supplements and extends the article entitled Imposing spatial order - an efficient system or chaos? Local spatial development plan - the scope of regulation. The article refers to the selected development parameters included in the Art. 15, paragraph 2, point 6 of the Spatial Planning and Land Development Act. The ambiguity of the terms used in this law and the concept of development term itself was indicated, which makes it difficult to draw up the local spatial development plans.

Some text excerpts of the article Imposing spatial order - an efficient system or chaos? Local spatial development plan - the scope of regulation. were deliberately repeated. For those who have not read it, this will help understand the issues discussed in this article.

In order to maintain the precision of the statement, a number of quotations have been used. The article is based on the law in force at the end of October 2021.

Key words: local spatial development plan, gross covered area, floor area ratio, development height, biologically active area

\footnotetext{
Anna Wieczorek - na Politechnice Warszawskiej ukończyła Wydział Architektury, Podyplomowe Studium Urbanistyki, Studium Doskonalenia Pedagogicznego oraz uzyskała dyplom doktora nauk technicznych. Posiada uprawnienia do projektowania w planowaniu przestrzennym oraz uprawnienia do pełnienia samodzielnych funkcji technicznych w budownictwie. Specjalizuje się w wykonywaniu projektów miejscowych planów zagospodarowania przestrzennego (główny projektant ponad 30 uchwalonych projektów planów miejscowych) oraz projektów studiów uwarunkowań i kierunków zagospodarowania przestrzennego gmin (główny projektant 5 uchwalonych studiów). Ma doświadczenie w pracy ze studentami - na Politechnice Warszawskiej i w Wyższej Szkole Przedsiębiorczości i Administracji w Lublinie. Należy do Mazowieckiej Okręgowej Izby Architektów z siedzibq w Warszawie oraz Pan-Europejskiej Federacji Ochrony Zabytków - Europa Nostra z siedzibq w Holandii.

Anna Wieczorek - graduate of the Warsaw University of Technology - Faculty of Architecture, Postgraduate Town Planning Studies, Pedagogical Study, PhD in technical science. Holds professional permits for spatial planning and is authorised to perform independent technical functions in construction. Specialises in the preparation of local spatial development plans (is the main designer of more than 30 approved local development plans) and draft studies of conditions and directions of the spatial development of municipalities (main designer of 5 approved studies). Has experience in working with students - at the Warsaw University of Technology and the University College of Enterprise and Administration in Lublin. Member of the Warsaw-based Masovian Chamber of Architects and the Pan-European Federation for Cultural Heritage, Europa Nostra based in the Netherlands.
} 
